\title{
Approach to operational mine planning: Case study Tamnava West
}

\author{
DEJAN R. STEVANOVIĆ, University of Belgrade, \\ Faculty of Mining and Geology, Belgrade \\ MIRJANA V. BANKOVIĆ, University of Belgrade, \\ Faculty of Mining and Geology, Belgrade \\ MILICA D. PEŠIĆ GEORGIADIS, University of Belgrade, \\ Faculty of Mining and Geology, Belgrade \\ RANKA M. STANKOVIĆ, University of Belgrade, \\ Faculty of Mining and Geology, Belgrade
}

\begin{abstract}
In contemporary mining industry is very difficult to achieve production targets and profit without investing effort in detailed excavation planning. It is especially true for deposits with complex geological structure and production technology, as is the case for many coal mines in Serbia. The majority of coal production is used for generation of electricity in power plant. This fact is the main reason why production objectives of coal mine and power plant are strongly connected. Due to the fluctuation of the coal quality, operational mine planning (as a part of coal homogenization process), is of critical importance for managing successful coal quality control and meeting criteria of power plant.

This paper investigates advantage of proper operational planning on coal quality control process and overall production performance. For better understanding case study is conducted on open pit Tamnava West field. Successful operational mine planning is almost impossible without use of modern software packages. For that reason in presented case study operational mine planning is done with Minex software.
\end{abstract}

Key words: operational planning, geological modeling, coal quality control, mining block and cut.

\section{INTRODUCTION}

Modern mining is characterized by continuous worsening of production conditions. This is particularly evident when considering the fact that the deposits on which exploitation is carried out are often, small in size, with poor quality and with complex structure and geometry, often in locations that have unfavorable infrastructure, or in regions with significant political instability.

In the vast majority, mining projects, that guarantee the realization of profits, are a thing of the past. Successful business in conditions of limited resources is impossible without many analysis of the technical and economic parameters and detailed planning of all possible scenarios of production.

Due to availability of the coal resources and their

Author's address: Dejan Stevanović, University of Belgrade, Faculty of Mining and Geology, Belgrade, Đušina 7

Paper received: 20.11.2014.

Paper accepted: 01.12.2014. price stability, coal is and will retain its important role in power generation in Europe and worldwide [1]. In Serbia, coal is the most important fuel in the generation of electricity, accounting for $65 \%$ of the power production [2].

This fact is the main reason why production objectives of coal mine and power plant are strongly connected. The power plant owner is interested to know in advance the quality of coal to be burnt which should meet maximal efficiency of power plant and the environmental regulations.

Coal quality control between the mine site and the utility plant is a complex problem owing to the variable nature of coal properties (heating value, sulfur, ash), even within the same coal seam. In order to ensure a normal and efficient operation of the power plants fed with coal it is necessary to reduce the variation of the coal and that is done through coal homogenization process. More about homogenization process can be found in the work of many authors $[3,4,5,6]$

Two places where coal homogenization can be conducted are at the mine site and at the stockyards [2]. 
Homogenization of coal in mine site can be achieved at:

- mining block (production of one excavator on one bench),

- the connecting conveyors (production of all excavator on different benches).

For the management of the coal homogenization process at the mining block level is especially important to have enough of in situ data, and to conduct quality operational planning. The importance of operational planning for coal quality control is stressed by Stevanović et. al. [7].

Also due to the complex nature of coal operational planning, usage of specialized commercial software is necessity.

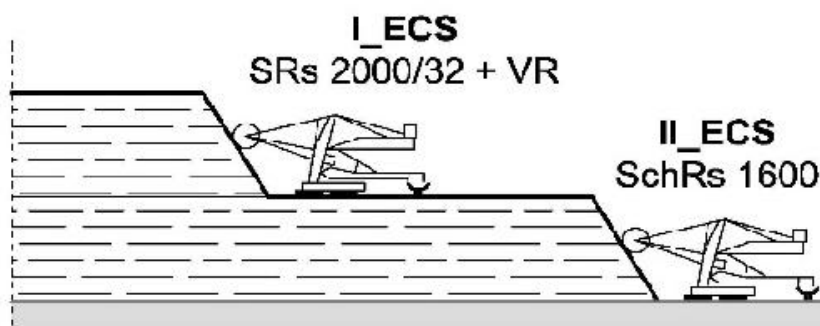

\section{CASE STUDY}

The case study is conducted on open pit Tamnava West field. Tamnava West is a part of Kolubara coal basin, and it operates under governance of Electric Power Industry of Serbia (EPS). Currently, Tamnava West is a biggest coal open pit in Serbia, with capacity of 13 million tons of coal per year.

The excavation technology of Tamnava West, is based on continuous mining equipment. Coal and interburden is excavated with 4 ECC systems (Bucketwheel Excavator - Conveyors-Crushing Plant), and 2 ECS systems (Bucketwheel Excavator- ConveyorsSpreader) are engaged on overburden excavation. General technological scheme of open pit Tamnava West is presented on Figure 1.

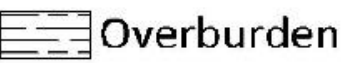

Coal

\section{I_ECC}

SchRs 630 II_ECC

SchRs 630 III_ECC IV_ECC

SchRs 630 ERs 1000

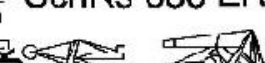

Figure 1 - General technological scheme of open pit Tamnava West

\subsection{Developing of technological model for coal} quality control

Minex is the recognized as one of world leading software for integrated geology and mine planning solutions. It is comprehensive tool specialized for coal and other stratified deposits, such as phosphate, zinc, bauxite, iron ore, and platinum. Minex covers almost every part of geological modeling and mine planning process. It provides a fast and powerful set of modules for surface or underground mines, long or short term planning.

Developing of technological model for operational planning and coal quality control in Minex for the Tamnava West open pit, was based on 6 steps:

- Preparation of data

- Geological modeling

- Ultimate pit design

- Design of pit benches

- Discretization of benches on mining blocks and cuts

- Reporting

\subsubsection{Preparation of data}

For the purpose of importing in Minex, the data went through many transformations. Borehole data where obtained from BpUBS (Integral data base of Serbian Coal Basins). This database stores all exploration drilling data from Kolubara Coal Basin, such as: basic information about drill hole (collar data), complete lithology and assaying data, geotechnical, hydrogeological, geophysical data.

This system can perform export of data to the different formats for use with mining and geological software's like Minex.

Nevertheless, it was necessary to do numerous levels of verification over this set of data before importing into the Minex data base:

- Checking of all 213 drill holes logs

- Checking of all lithological intervals (11298 records), followed by lithological and ply / rock parting coding

- Checking sample intervals, individual ply analysis and composite assays (5109 records, average sample length is $0.8 \mathrm{~m}$ ),

- Checking drill hole collar coordinates to eliminate any obvious errors in location

Only portion of mine is used in this study since it has sufficient number of geological exploration data, necessary for production planning and operational management of coal quality, Figure 2. 


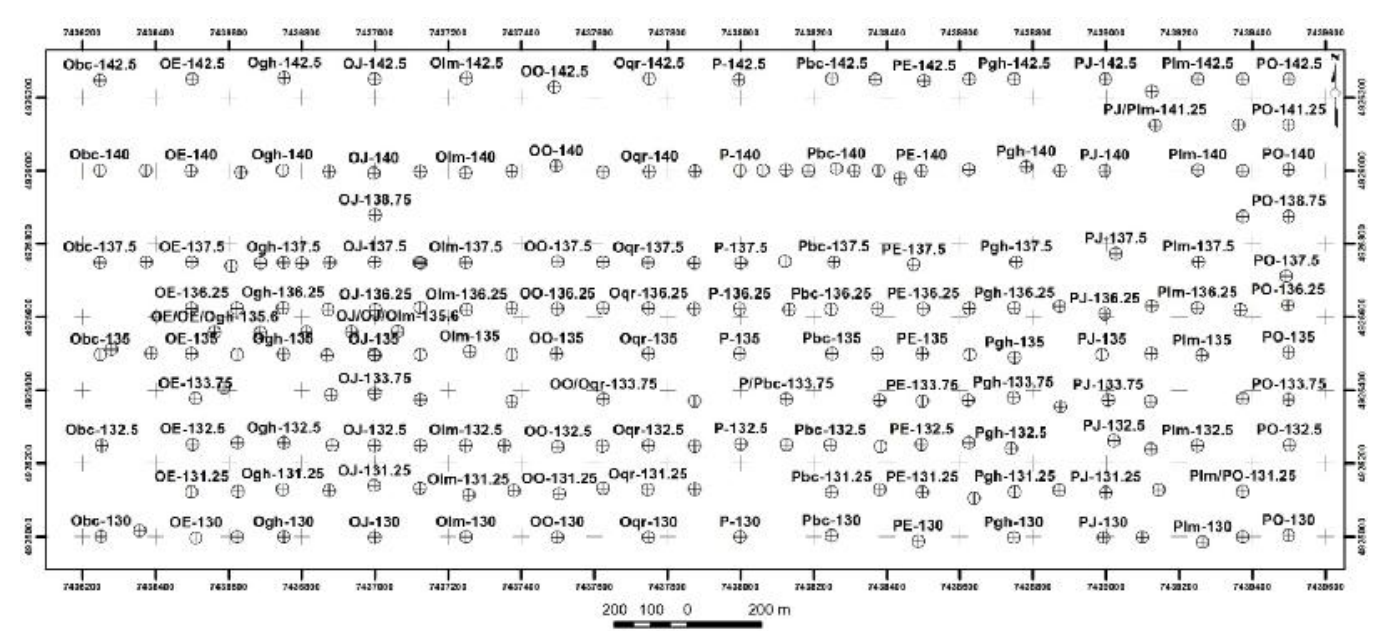

Figure 2 - Portion of the pit Tamnava West

All the boreholes were drilled vertically, but the regional dip of the Tamnava West deposit in average is $3^{\circ}$, the apparent thickness of the intersected coal seams closely approximates the true thickness (except in the western part where intensive parting starts, dip is going over $3^{\circ}$ locally).

Drill holes that had less than $86 \%$ recovery through any coal seam, were discounted and not included for coal estimation.
The 11298 lithological records where coded based on Minex lithology code, flowed by code merging based on minimum mineable thickness of $0.5 \mathrm{~m}$. The minimum mineable thickness thresholds have been set at 0.5 meters for coal seams and partings based on the type of mining equipment, experience of the operators and other operating conditions. After merging the number of record fell on 2606 (Figure 3). And the final phase was basement /seams/partings/inerburden/overburden coding.
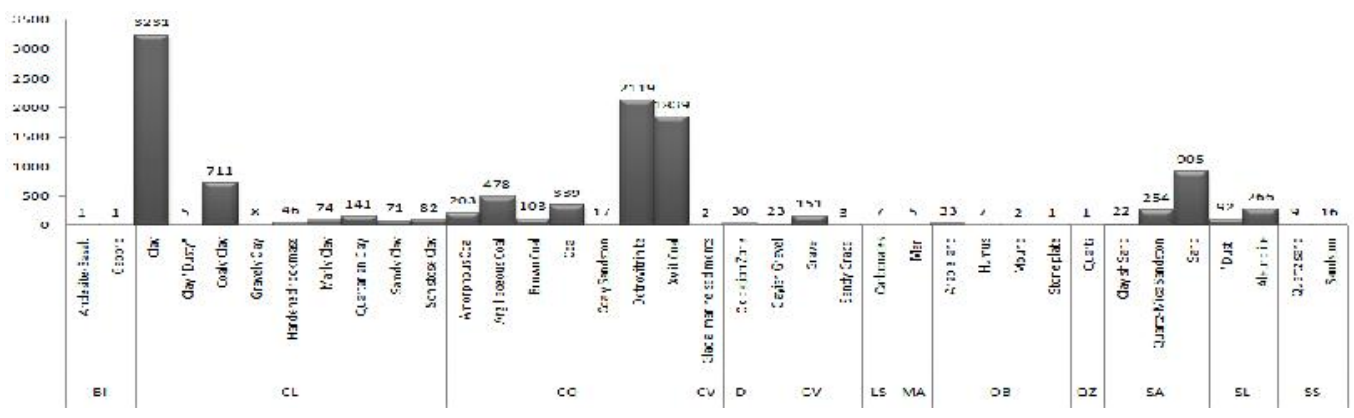

Figure 3 - Lithology/coding chart

In total there were 5109 drill hole samples taken from the 185 drill holes, 4045 coal samples and 1064 rock partings samples (dominantly clay). Analysis

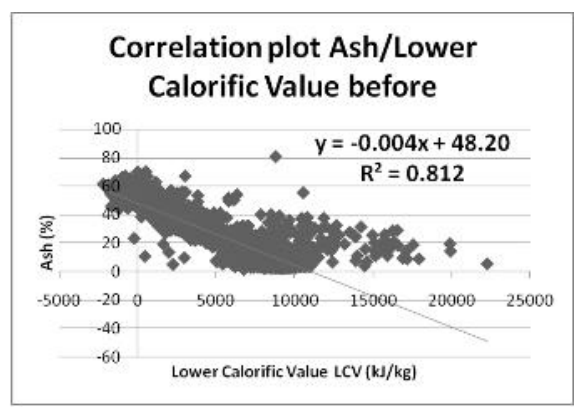

testing was conducted for Moisture, Ash, Lower (LVC) and Upper Calorific Value. After preliminary statistical analyses the 367 sample where rejected based on correlation between Ash and LCV (Figure 4).

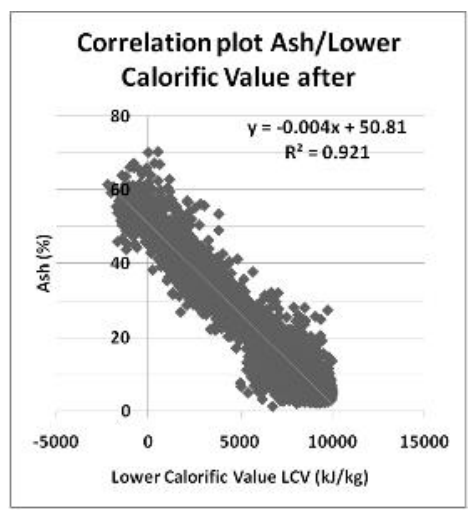

Figure 4 - Preliminary statistic analyses of Ash/LCV corelation 


\subsubsection{Geological Modeling}

The geological model for Tamnava West was developed using the Minex software package with the data provided by EPS. To provide a better structural model, the technique within Minex called the "Splitting" and "Father and Son" concept was applied and the gridding mesh size was set at $25 \mathrm{~m} \times 25 \mathrm{~m}$ to cover all boreholes. An exceptionally large scan distance of $35,000 \mathrm{~m}$ was selected for seam General Purpose interpolation, and for assay data Inverse Distance, power 2 . A total of 25 coal sub-seam plies, 46 partings (14 sandstone and 32 clay), clay basement, interburden sandstone and overburden river sediments have been modeled within a stratigraphic section up to $98 \mathrm{~m}$ thick. The reason for so detail model lies in the fact that this model is base for coal homogenization process, so it need to represent as real as possible every lithological member within minimum mineable coal thickness and minimum removable parting.

The Tamnava West deposit is characterized by geology that is of moderate complexity, both with respect to stratigraphy and structure. The geology was originally defined by earlier work of geologists from Tamnava West mine. The Tamnava West consists of one seam that is divided in two correlatable seam plies with interburden sandstone. These two seam plies are divided into lower and upper units by clay and sandstone partings (maximum up to 9 sub-seam plies). The individual plies maintain relatively constant thickness over the strike length, while most of the variation takes place in the inner rock parting material mainly clay (Figure 5).

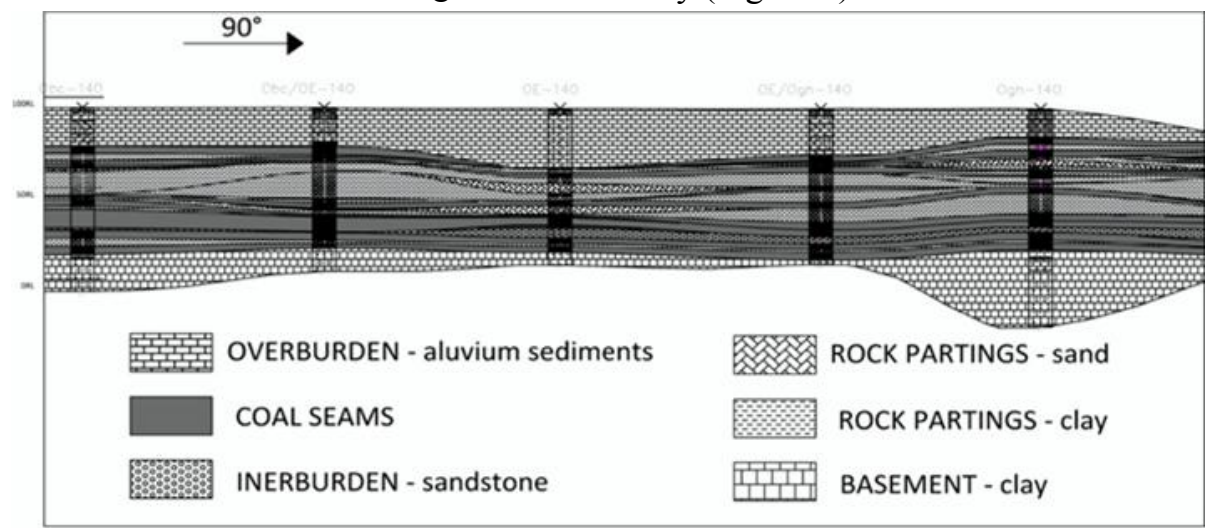

Figure 5 - Geological cross - section in Tamnava West

\subsubsection{Ultimate pit design}

Long term production planning is specified by existing mine documentation. Case study, is based on this developed long term production planning. In this regard, pit limits, geometry of benches or technology, was not a part of interest for this study, and are simply as it is.

\subsubsection{Design of pit benches}

Design of pit benches is one of the most important and critical phases in mine planning of pit production. It's a part of long term planning, and if done inappropriately can have significant impact on overall pit performance. This is especially true for continuous mining technology where pit benches are usually surfaces (not horizontal planes). Many factors have influence on design of pit benches and main are:

- capacity requirements

- geotechnical conditions

- equipment limitations

- coal quality control, etc.

All this factors are analyzed for purpose of bench design for case of Tamnava West. Special attention was paid to the aspect of selective excavation. In this way the first step of quality control is performed. Bench surfaces designed in this manner allow less dilution effects and greater recovery of reserves. For the case of Tamnava West minimal minable thickens of coal seam was set to $0,5 \mathrm{~m}$.

The final design of benches is done in Minex. Although Minex has module for bench design, due to complex nature of bench geometry for Tamnava West, final bench design is done semi automatically. Created 3D model of benches is grid type, and as such is suitable for interaction with created geological grid model.

\subsubsection{Discretization of pit benches on mining blocks}

In order to make operational planning of coal production and manage coal quality control, it is necessary to know what each excavator at a certain moment is excavating. The main precondition for planning on this level is discretization of each coal bench on mining blocks.

Bench discretization to mining block level is performed in two steps:

1. Bench area is divided in the direction of operations advancing, on the parts which correspond 
to the width of the mining blocks (strips). This width is unique for each coal bench and depends on the characteristics of bucket wheel excavator (BWE) engaged on that bench (it matches the actual width of the block which is excavated by particular BWE).

2. Also, bench area is divided parallel to the direction of excavation advancing. This division simulates the advancing of each excavator in the mining block, i.e. mining block length. Block length is the unique value of each bench and is related to technological capabilities of engaged excavator on the specific bench.

Figure 6. presents area of pit bench for I ECC system, discretized on mining block.

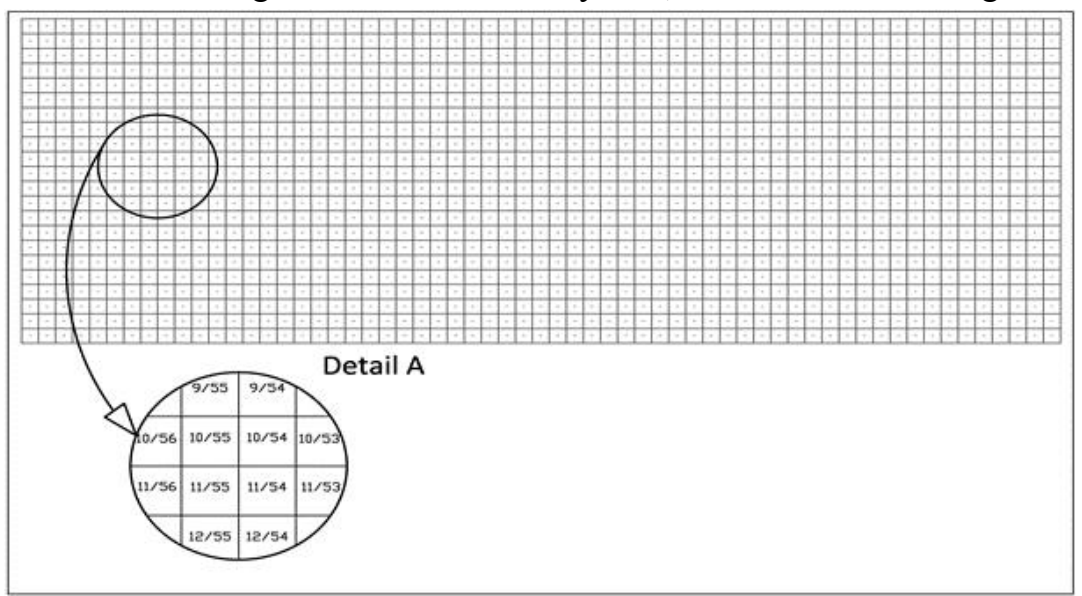

Figure 6 - presents area of pit bench for I ECC system, discretized on mining block.

For all four designed coal benches, the same process is performed. During the discretization, technological features of the equipment engaged on each bench were considered.

In this way, geometric framework necessary for the consideration of the qualitative characteristics and production planning for the mining block level, is formed. In the next step it is necessary to join the geological characteristics to the formed geometric framework, and generate reserves for each coal bench.

\subsubsection{Generating reserves on coal benches}

In order to determine the quantity of coal and waste, and the quality on cut level, for each mining block, it is necessary to integrate created bench geometry with formed model. This actually means that the geometry of the bench should be joined with reserves of coal and waste. In practical terms, the problem is solved by discretization of developed geological model on mining blocks.

Figure 7. shows the bench divided into mining blocks. Bench dimensions are limited to portion of coal field, at which the case study is conducted.

Discretization on the mining blocks for one excavator strip is shown on figure 7 . For operational planning, this representation of mining blocks (arranged in one excavator pass) is very important because it provides the efficient way of operational planning for each BWE in advance.

Single mining block is shown also on Figure 7. Because geometry of a mining block is connected

with geological model it is possible to determine the reserves of coal and waste, as well as the quality achieved by excavating the each block on each bench.

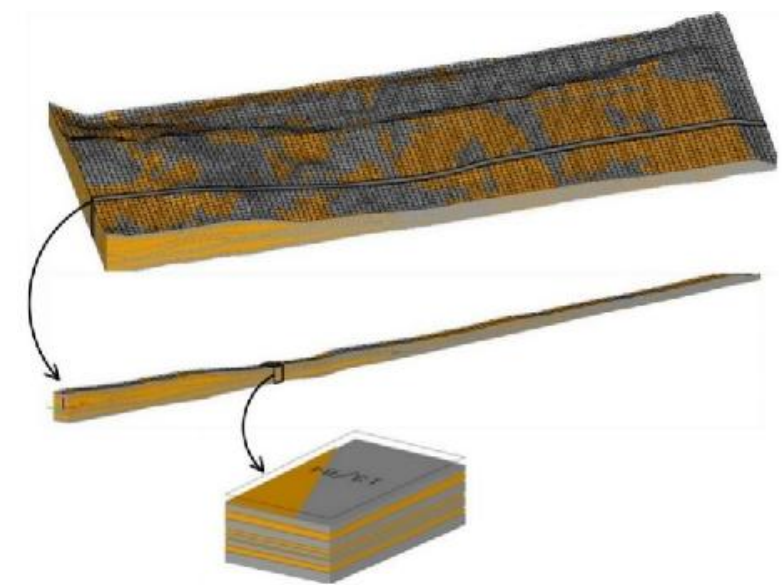

Figure 7 - Bench discretization on mining block level

\subsubsection{Discretization on mining cuts level of and reporting}

Discretization of geological model on mining blocks is suitable for both long and short range production planning, but it can't provide answers regarding current excavation (real time excavation).

For that purpose, discretization of model needs to be further conducted, to the level of excavator's cuts. The reason for this is excavation technology of bucket wheel excavator (BWE) which is based on individually excavation of one cut. In this sense every mining block is divided in several cuts, and BWE excavation is 
conducted from top cut Figure 8. Technology of BWE is very well explained by many authors $[8,9]$.

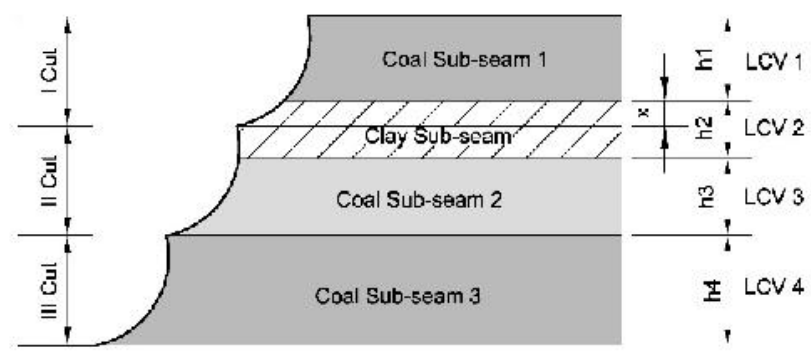

Figure 8 - Mining block division on BWE cuts

The process of dividing mining block on cuts is under influence of these factors:

- Technical characteristic of BWE

- Quality target that we wont to achieve

- Capacity of BWE and total daily production

Technical characteristics of BWE is limiting factor for cuts height, which can be in range from maximal to minimal value regarding a characteristics of particular BWE. For the case of SchRs 630 (BWE on Tamnava - West) maximal height of sub benches is $7 \mathrm{~m}$ and minimal height is $1 \mathrm{~m}$.

Quality target is set by the needs of Thermal power plant Nikola Tesla, main user of coal from Tamnava - West. By agreement between power plant and Kolubara Basin, delivered coal should have lower calorific value (LCV) in range $6700 \mathrm{~kJ} / \mathrm{kg} \pm 5 \%$. The goal of operational planning of excavation is to achieve this range as much as possible. LCV for first mining cut (Figure 8.) is defined with equations:

$$
\mathrm{LCV}_{\text {I cut }}=\frac{L C V 1 \cdot h 1+L C V 2 \cdot h 2 \cdot x}{h 1+h 2 \cdot x},(\mathrm{~kJ} / \mathrm{kg})
$$

LCV1 - lower calorific value of coal sub-seam 1

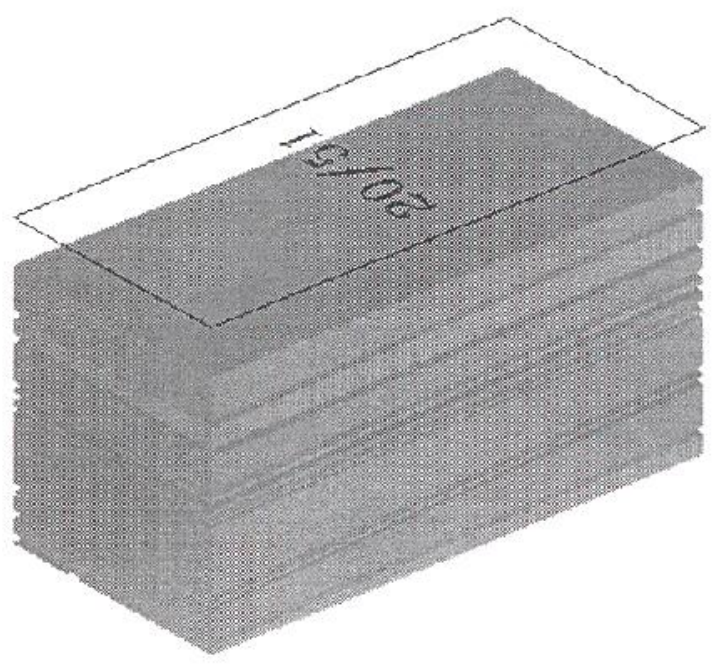

h1 - height of coal sub-seam 1

LCV2 - lower calorific value for clay sub-seam h2 - height of clay sub-seam

$\mathrm{x}$ - part of clay sub-seam (\%)

Capacity of BWE is usually greatly affected by selective excavation (excavation controlled by coal quality). For successful production plan both criteria (quality and capacity) must be met.

Using flexible structure of Minex software, every mining block is divided in excavator cuts. With Minex module for reporting, it's now possible to keep track of quantity (waste and coal) and quality (lower calorific value, moisture, sulfur content) on the level of excavator cut. The example of mining block divided in excavator's cuts and reports based on that division is shown on Figure 9.

As can be seen from the Figure 9. mining block (\# 20/51) comprises from 5 seams of coal and the same number of waste (clay) seams. LCV significantly varies from seam to sub-seam and average for whole mining block is $5.621 \mathrm{~kJ} / \mathrm{kg}$. All this suggest that selective excavation must be conduct in order to achieve desirable LCV within coal mining cuts. Example mining block divided in 5 mining cuts is shown on the Figure 9b. Three cuts (cut 1, cut 3 and cut 4$)$ have the LCV in prescribed limits $(6.700 \mathrm{~kJ} / \mathrm{kg}$ $\pm 5 \%)$ and they can be considered as coal cuts. Other two cuts (cut 2 and cut 5 ) are defined as waste. In order to achieve LCV in prescribed limits three coal cuts have to include seams of clay (Figure 9b). For that reason clay seam G31 is divided between cut 1 and cut 2 , and clay seam G18 is divided between cut 4 and cut 5 . In this way, not only desired quality is achieved, but also the total coal reserves are increased by $1.052 \mathrm{t}$.

\begin{tabular}{|c|c|c|c|c|c|}
\hline SEAM & $\begin{array}{c}\text { WAST } \\
\left(\mathrm{m}^{3}\right)\end{array}$ & $\begin{array}{c}\text { COAL } \\
\left(\mathrm{m}^{3}\right)\end{array}$ & $\begin{array}{c}\text { COAL } \\
(\mathrm{t})\end{array}$ & $\begin{array}{c}\text { THICKN. } \\
(\mathrm{m})\end{array}$ & $\begin{array}{c}\text { LCV } \\
(\mathrm{k} / \mathrm{kg})\end{array}$ \\
\hline $\mathrm{DF}$ & $/$ & 1676 & 2011 & 1.58 & 7350 \\
\hline $\mathrm{G} 31$ & 1312 & $/$ & $/$ & 1.31 & 0 \\
\hline $\mathrm{DE}$ & $/$ & 1574 & 1888 & 1.57 & 6959 \\
\hline $\mathrm{G} 27$ & 565 & $/$ & $/$ & 0.57 & 3717 \\
\hline $\mathrm{DD} 4$ & $/$ & 521 & 625 & 0.52 & 9442 \\
\hline $\mathrm{G} 25$ & 237 & $/$ & $/$ & 0.24 & 1275 \\
\hline $\mathrm{DD}$ & $/$ & 3035 & 3642 & 3.04 & 7495 \\
\hline $\mathrm{G} 20$ & 331 & $/$ & $/$ & 0.33 & 3463 \\
\hline $\mathrm{DD} 2$ & $/$ & 1564 & 1876 & 1.56 & 7421 \\
\hline $\mathrm{G} 18$ & 1272 & $/$ & $/$ & 1.27 & 1452 \\
\hline
\end{tabular}

a) Minig block (\#20/51) with basic quantity and quality parameters foer every seam 


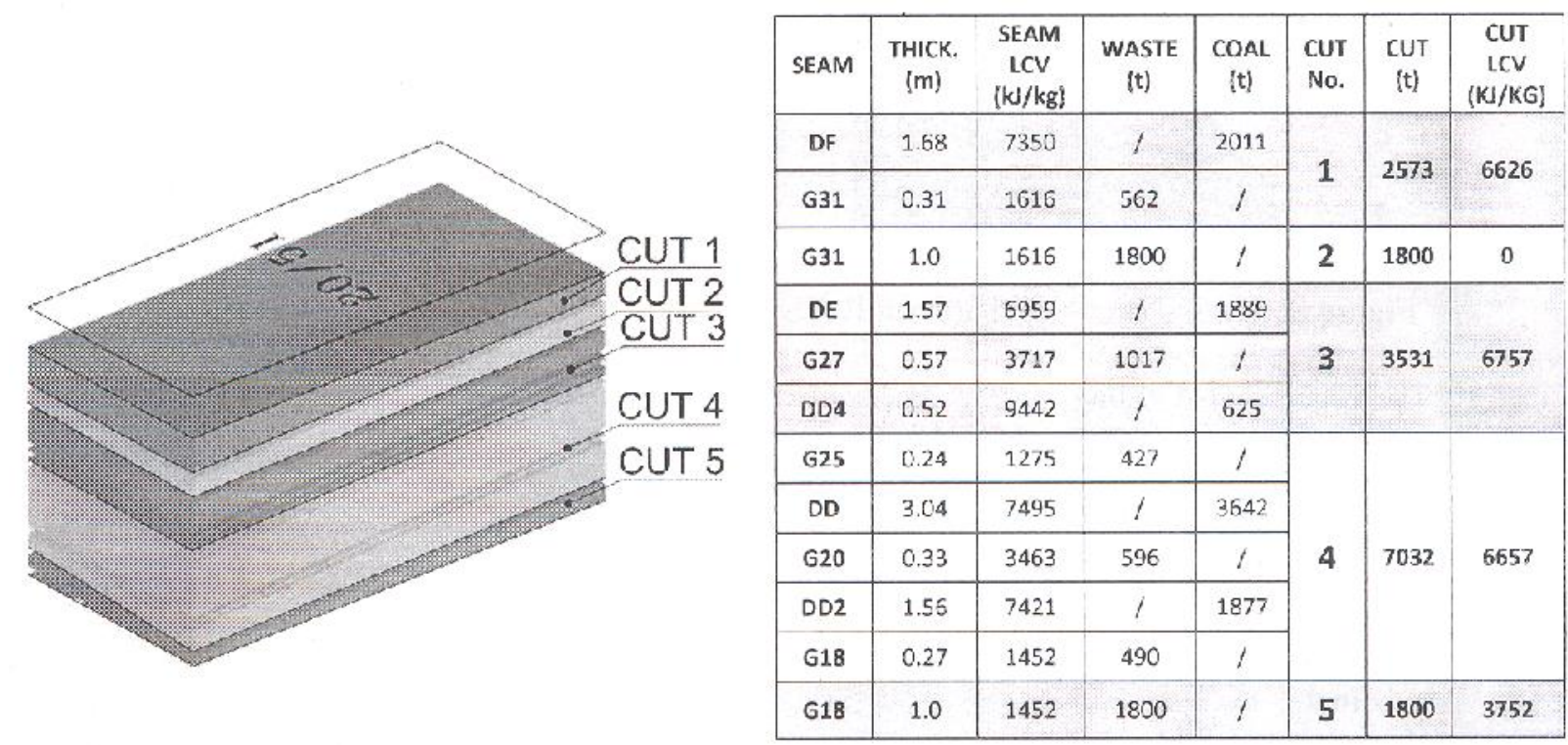

b) Mininig block(\#20/51)divided on a BWE cuts with basic quantity and quality parameters for each cut Figure 9 - Mining block divided in excavator's cuts

\section{CONCLUSION}

In today mining industry is very difficult to achieve production targets and profit without giving special attention and effort in detailed mine planning. It is especially true for deposits with complex geological structure and production technology, as is the case of Tamnava-West coal pit. The coal quality control management is of vital importance for successful production since coal mine and power plant objectives are strongly connected.

Coal quality control is complex and comprehensive problem which depends of many factors and elements of production system:

- geological in situ data should be credible and with sufficient amount,

- geological model should provide realistic interpretation of real structural a qualitative characteristics of deposit

- long, short and operational planning should incorporate all production goals and constrains: capacity and quality requirements, geotechnical conditions, equipment limitations etc.

- discipline should be kept on high level thought every step of production process.

Operational mine planning is mandatory part of coal quality control management. Successful operational mine planning is almost impossible without use of modern software packages. In this paper, Minex was the software tool used for geological modeling and operational planning of coal production.

The advantages of proper operational planning are presented on the example of one mining block. Overall
LCV of mining block was $5.621 \mathrm{~kJ} / \mathrm{kg}$ and that is significantly below proscribed values $(6.700 \pm 5 \%)$. At the same time overall LCV of coal sub-seam in same mining block was $7.473 \mathrm{~kJ} / \mathrm{kg}$ (much above proscribed values). Simple selective excavation will not provide the strict requirements of power plant regarding LCV. Thanks to detailed geological model generated in Minex, it was possible to optimize division of mining block in BWE cuts. In this way not only LCV requirements of power plant were met, but also the total coal reserves are increased by $1.052 \mathrm{t}$.

At the end it should be noted that although presented analysis is performed using Minex software, like any commercial tool, Minex has many advantages and disadvantages. Geological modeling in Minex requires a lot of expertise and detailed knowledge of the deposit characteristics, but also is the practical solution for developing, verification, analysis and updating of deposit model.

Since Minex is not specially developed for continuous mining technology operational mine planning process is feasible, but not fully practical. In Minex for every excavation cut, separate grid must be generated, and this is very time consuming and only semi-automated or completely manual process. In that sense it is better to develop custom software capable to cope with problems that are unique for specific open pit mine.

Good example of custom made software is SUKU, software package developed on Faculty for Mining and Geology (Belgrade) with specialized tools for coal quality control management in a coal mines with continuous technology. 


\section{ACKNOWLEDGEMENT}

This paper was realized as a part of the project "Improvement of Lignite Opencast Technology in Order to Increase Energy Efficiency and Occupational Safety" (TR 33039) financed by the Ministry of Education and Science of the Republic of Serbia within the framework of Programme of research in the field of technological development for the period 2011-2014.

\section{REFERENCES}

[1] International energy outlook US Energy Information administration, 2011.

[2] Ignjatović D., Knežević D., Kolonja B., Lilić N., Stanković R, Upravljanje kvalitetom uglja ("Coal quality management"), University of Belgrade, Faculty of mining and geology, Belgrade, 2007.

[3] Carpenter M. A., Coal blending for power stations, IEA Coal Research, London, 1995.

[4] Wall. T et. al, A review of the state of the art in coal blending for power generation final report - project 3.16, Cooperative research centre for black coal utilization, Callaghan, 2001.
[5] Galetakis M, Pavloudakis F, The effect of lignite quality variation on the efficiency of on-line ash analyzers, International Journal of Coal Geology, vol. 80, pp. 145-156, 2009.

[6] Beretta F, Costa J, Koppe J, Souza V, Reducing coal quality variability with size optimization of blending piles, Fourth World Conference on Sampling \& Blending, The Southern African Institute of Mining and Metallurgy, 2009.

[7] Stevanović D, Kolonja B, Stanković R, Knežević D, Banković M, Application of stochastic models for mine planning and coal quality control, Thermal Science, DOI REFERENCE: 10.2298/TSC130201031S, 2013. http://thermalscience.vinca.rs/pdfs/papers-2013/TSCI130201031S.pdf, 2013.

[8] [Pavlović V, Ignjatović D, Selective opencast coal mining by continuous systems, Faculty of Mining and Geology, Belgrade, 2012.

[9] Drebenstendt C, Countinius surface mining - last developments in mine planning, equipment and environmental protection, Freiberg, 2010.

\section{REZIME}

\section{PRISTUP OPERATIVNOM PLANIRANJU RUDNIKA: PRIMER TAMNAVA ZAPADNO POLJE}

U savremenoj rudarskoj industriji vrlo je teško postići ciljanu proizvodnju i profit bez ulaganja velikog napora u detaljno planiranje otkopavanja. To je naročito tačno za ležišta sa kompleksnom geološkom strukturom i tehnologijom proizvodnje, kao što je slučaj sa mnogim rudnicima uglja u Srbiji. Najveći deo proizvodnje uglja se koristi za dobijanje električne energije u termoelektranama. Ova činjenica je glavni razlog uske povezanosti ciljeva proizvodnje rudnika uglja i termoelektrane. Usled promenljivosti kvaliteta uglja, operativno planiranje kopa (kao deo procesa homogenizacije uglja), je od ključnog značaja za uspešno sprovođenje kontrole kvaliteta uglja i ispunjavanje kriterijuma termoelektrane.

Ovaj rad istražuje značaj pravilnog operativnog planiranja u procesu kontrole kvaliteta uglja. Za bolje razumevanje predstavljen je primer na površinskom kopu Tamnava Zapadno polje. Uspešno operativno planiranje rudnika je skoro nemoguće bez upotrebe modernih softverskih paketa. Iz tog razloga je prikazani primer operativnog planiranja je uraden u programskom paketu Minex.

Ključne reči: operativno planiranje, geološko modeliranje, kontrola kvaliteta uglja, bagerski blok i rez 